the sociocultural environment of the subjugated people of Mozambique.

I have two major wishes and two minor points that were left unfulfilled by this book. The minor, editorial ones, first. The excellent photographs would be even more valuable if captions included a date when they were taken. Also, a glossary of Portuguese andMozambican terms, which Isaacman uses often, rightly and compellingly, can help those readers less well embedded in Mozambican society.

A more critical issue is that I do not see a major theoretical thrust around which the author's narrative and the Mozambican voices are assembled. His approach is to assert the agency, autonomy, and resourcefulness of the rural Mozambicans to eke out a living, to cope with and to forge resistance against the colonial cotton policy by documenting at the same time in admiring detail all the facets of local and international cotton policy. At the end, it leaves the reader with an encompassing description of social change: increase of rural differentiation, forms of everyday resistance, ecological change and issues of malnutrition, hunger and changes in staple foods, accounts of gross human rights violations. Further, issues that deal with the powers of the Portuguese colonizer are ever present, yet an overarching theme seems to be left unnamed. Mentioned in passing is Sen's theory of the "entitlement crisis" and considerations that deal with vulnerability. Between the lines are glimpses of the world system theory of how the peripheral colonizer Portugal incorporated Mozambique --a far away place in the periphery of the periphery-- into the global market. Yet a discussion of these major themes, i.e. entitlement crisis, vulnerability, and globalization, is conspicuously absent. I suspect, that this, and this is my second point, seems to be related to the fact that Isaacman only scantily discusses 'the colonial state' or 'the colonial administration' but presents it as if it were one unified and partly unifying force over the decades that are covered in this book. Having said that, I hasten to add that not many people would be able to address these issues all hinted at in footnotes and short asides, as adeptly as Isaacman. How to conduct such a discussion, Isaacman himself has set standards in this book that will be hard to follow. An important book, indeed.

\title{
The Mekong Delta: Ecology, Economy and Revolution, 1860-1960, by Pierre Brocheux. Madison: The Center for Southeast Asian Studies, University of Wisconsin, 1995. xvii, 270 pp.
}

\section{Reviewed by Joakim Öjendal, Göteborg Center for East and Southeast Asian Studies (GESEAS), Göteborg University, Sweden.}

\section{"IN THE BEGINNING THERE WAS WATER" - THE MEKONG DELTA AS A HISTORICAL SUBJECT}

The Mekong Delta is one of the areas in the world where making a living is a work of art. Marguerite Duras made her childhood experience from the delta into a literary work of art in her Un Barrage Contre le Pacifique. Albeit from 1950, that book probably has brought the Mekong Delta into more living rooms of non-Vietnamese and nonexperts than any other source. The family in her book--destitute, desperate and confused--hangs on to a piece of property that they themselves dislike and find impossible to make a good living 
from. Water--the curse and the blessing of the delta--makes the land salty and soaked because the unregulated water regime. What is even more impossible for this family to understand is what is happening in their surroundings; in spite of being long-time residents, they have little idea of how the Vietnamese society around them operates. Nonetheless, they are somehow rooted to the land, but in the light of deteriorating economy and their inability to manage the property, they break up and leave, first the delta, and then Vietnam. This book could be read as the beginning of the end of French colonial engagement in the delta. In a more down-to-earth, academically comprehensive fashion Pierre Brocheux has (also initiated by his childhood experiences) created a totally different piece in his book. It is very different, but tells the same story.

The Mekong Delta is one of the globe's major delta areas. It receives and disburses 475 billion cubic meters of water every year from the mighty Mekong River, which is the tenth largest in the world and the largest unregulated river. It emanates far up in the Himalayas, passing China, Burma, Thailand, Laos and Cambodia before it enters Vietnam Already in Cambodia, the river spreads into several main arteries that through nine arms disburse into the sea. That is also how the river has earned its name in Vietnam: "The ninetailed dragon" -- Сии Long. (It is sometimes said in Vietnam, with a low voice, that "It really does only have eight arms, but nine is a lucky number, so we added one"). For the major part of the delta the river spreads into a crisscross pattern of water ways, making the entire area with the conditions that the river and its water sets. The delta's history is marked by both richness and hardships, and parts of it have even been largely uninhabited and "unconquered" by the otherwise historically fiercely rivaling empires on Mainland Southeast Asia. Still today the borders are basically undefined, pushing Vietnam and Cambodia into a centuries-old quarrel over the exact demarcation of the borderline.

As the competition for space increases with population growth (in Vietnam there are approximately 900 persons per arable square kilometer), the delta becomes increasingly densely populated. Moreover, with a Vietnamese growth-led, export-oriented development strategy, the delta is viewed as an area with a huge potential. It is already the grain basket of Vietnam, producing about half of the national rice harvest, and it is considered to have a much greater potential than, for instance, the Red River Delta. It is, however, also an area prone to disasters: in the short term from salt water intrusion, floods, or both.

In the long term the delta faces even more serious problems. The Mekong River waters have been subject to a drawn out regional political dispute primarily involving the four lower basin countries (Laos, Thailand, Cambodia and Vietnam). A new agreement on resource cooperation was concluded in April 1995. Whereas the former agreement gave the downstream countries a virtual veto to water use, the new accord basically gives the upstream countries the right to use the water as long as they inform downstream countries. As fresh water becomes all the more valuable there is a serious risk that less water, and of worse quality, will arrive at the Delta. Certainly upstream countries, including China, have plans for the usage of the water. The Delta is thus also prone to long-term degradation due to the problem of intensifying upstream water usage and increased pollution from industrializaton and the modernizaton of agriculture. With increasing population pressure, disasters will become more disastrous. And as some ecologists like to point out, certain areas in the world ought not to be heavily populated. They may be able to carry the pressure in most years, but "disasters" are an integral part of their character, and not just repeated "bad luck." To support increasing population pressure then, it is sometimes argued, is to beg for disasters. 
Thus, with its high potential for agricultural development and vulnerability to disaster, the Mekong Delta is likely to be an area that we need to understand more fully. Pierre Brocheux has given us an instrument for doing just that, and from this point of view, his study is extremely timely. He has set out to capture a hundred years of social evolution confined within the parameters of the delta's very special ecology and its habit of producing revolutions. Brocheux takes us on a tour from the earliest French endeavors in the delta right up to the beginning of the national/communist war with the U.S. His interest lies predominantly with the Mien Tay, the area west of the Mekong mainstream, and the overarching question of the book is how the French arrival came about and how it affected the society.

In the first chapters, Brocheux describes the natural preconditions for the delta and here, as in much of the book, the author's knowledge goes beyond simple textbook skills. The early history of the delta--remember that the Vietnamese did not arrive in large numbers until the early ninetieth century through their Nam Tien (March to the South)--is told, albeit not very much is known about it. As one of the pioneering Vietnamese mandarins expressed it in 1818 when he entered the western part of delta. "This sacred place, which had been hidden to the eyes, had not yet been trod by any human foot" (p. 10). In Mien Tay the Chinese arrived just before the Vietnamese, and the Khmer, at the time the "original" people of the (western) delta, were few and scattered over a large area.

When the French arrived in the 1860s to take control over the delta region, the Vietnamese control of the area was still to be established and consolidated. The French met some resistance, but it was largely suppressed by 1875 . Not surprisingly, the French in their engineering approach to "development," tried to get control of the waterways and indeed a large number of channels were dug which drastically increased the transportation capability and agricultural productivity. Huge areas were drained between 1890 and 1925, and rice land could be expanded considerably.

French colonialism created a massive ecological as well as economic transformation. Thousands of miles of canals were dug to drain the swamps and vast stretches of mangrove felled. Thus, Mien Tay was opened to large-scale human habitation and agricultural cultivation (p. xvii).

Indeed the delta emerged in a short time as one of the major rice-exporting areas of the world. For the French, and for the Vietnamese, the gradual occupation of the delta resembles that of the "Wild West" in the US; land was free, few rules were applied, life was tough but the result for those who succeeded could be extremely good. Some got rich. Others became landless and grindingly poor. The difference was often decided by arbitrarily acting authorities, a failed harvest or careless money lending and spending.

The area apparently went through a booming era even as major hardships were experienced. Far too often the person clearing the land seems to have run into trouble and been forced to give up their land, becoming a part of a landless trasproletariat or farming indirectly for an absent landlord, or moving further west clearing new land. Uncertainties in harvests emanating from hazardous climatic circumstances seems apparently was one of the major stumbling blocks for the small farmer; especially pronounced due to the extreme monoculture of rice. The Vietnamese peasantry was squeezed between the Chinese rice monopoly, the Indian money lenders, the French colonial authorities, and the large land owners (French, or Vietnamese rewarded by the French for there cooperation). 
Land grabbing, unequal exchange conditions, forced labor, manipulated prices, and conflicts over land and water seem to have been the order of the day. The story is common: the "underdog" paid the price.

The Mien Tay area had two main features Brocheux tells us, "it was rural and it was plural"; there were Chinese, Vietnamese, French, Khmer, Indians and Chams. Internal conflicts were historically well known, but the French presence seems to have put a lid on its and, at least made the different ethnic groups accept some degree of co-existence. The Khmer were more numerous close to the mountains and in the west part of the delta, the Chinese were more urban oriented and the Chams in rather sealed off self-sufficient communities. Socially speaking, two groups dominated: the dien chu (landowners) and the ta dien (tenant farmers). The former, group included both the absent large landowner, often drawing discontent by lack of responsibility, and the small land owner, whose living conditions were not necessarily very different from those of the ta dien. This is a pattern we recognize from other parts of Indochina.

Although the period around the turn of the century was tough enough, the period to come, leading up to the second world war, became even more difficult for the people of the Delta region. Brocheux tells us about the reformation of the society and how class conflicts, religious sects and the early communist movements emerged; he convinces us of the devastating effects brought to the delta by the world depression in the early 1930s; he tells us about the subsequent recovery in the late 1930s and how the turmoil of the second world war reached the delta. In the end of the book we approach a history that is somewhat more familiar, researched and written about in other parts of Vietnam--the preface to independence from the French and the run-up to the war against the U.S., and the subsequent degenerated South Vietnamese regimes. The book finishes with a synthesis of the covered period.

Brocheux' book is well researched. The French as well as the Vietnamese source materials are extensive. Frequent references are made to documents varying from French official material, to Vietnamese daily papers, to letters exchanged between actors in the delta, and so forth. We are typically taken into the debates on various issues of the time and, understanding that sources outside the French archives must be difficult to obtain, Brocheux has done good work. Moreover, his deep knowledge of the area adds credibility and flavor to his accounts.

The book's subtitle--"Ecology, Economy and Revolution..."-is, however, somewhat off the mark for two reasons. First, "Agricultural" would have been a more proper word than "Ecology." The natural conditions are discussed, but no attempts are made to systematically try to understand how scarcities in general and biophysical constraints in particular affect societal development. Thus the study takes only a little step towards understanding a realm in serious need of attention. Secondly, while "Revolution" is a safe word in regard to the Mekong Delta, the time period chosen places it inside two major "revolutions" in the delta. Two of the major periods of social change must be the period before the French arrival as compared to after the French arrival, and the period taking the delta from a largely colonial set up to one of more genuine independence; i.e. through the 1960s and 1970s. This is neither to say that the period chosen was free of "change," or uninteresting. One could, however, argue that "revolution" is not the most appropriate label for this period.

On the critical side, as a reader more interested with the dynamics of the region rather than historical empirical data as such, one lacks interpretation, analysis and perhaps a hypothesis on which Brocheux could test his material. Tellingly, the introduction and the 
conclusion are but a few pages each, in spite of the fact that there is an overwhelmingly rich information base to dig from. This becomes somewhat frustrating as there is no reason to believe that Brocheux lacks this capacity; there are shorter, and highly interesting, parts of a more analytical nature in the book. Moreover, judging from his previous titles, Brocheux has a great deal to say here. In a similar vein it feels strange reading an academic book on revolution in the Mekong Delta that does not engage in the debate on causes for revolution and discussions on where and why Vietnamese nationalism was born (cf. Anderson 1983). In fact rebellion, revolution and opposition emerge seamlessly from a docile, subdued and politically unorganized peasantry in Brocheux' book. A lot of historical evidence is displayed, but little analysis is offered.

Having said that, this work must be considered as a major contribution to the factual knowledge of life in the Mekong Delta in this particular period, and although it may be lacking a more thorough analysis, the reader is free to make his or her own conclusions. As such the book is a more usable tool for the student of Vietnam than a part of the ongoing debate on revolution and nationalism. It is more of a sociological text than a story of ecological evolution, and it is more of a history of a part of Vietnam than an input to the development debate on the resources of the Mekong River.

The publisher--the Center for Southeast Asian Studies, University of Wisconsin has overall done a good job. No errors, well drawn maps and charts, and a nice layout. The book is all-in-all 270 pages of which 50 pages are devoted to various lists, references and appendices. A special reference should be made to the fairly extensive glossary list, allowing the reader to take full advantage of Brocheux's consequent use of Vietnamese terms, which in turn, adds a degree of exactness in his writings. There are also a number of interesting appendices reprinting a number original documents. One misses an index, however, which would have been particularly useful in light of the factually rich text. In addition, (all plublishers, please take note) placing the notes in the end of the book severely hampers a comfortable and distinct reading. There might be good publishing reasons for this, but the reader does not benefit from it.

In a way Brocheux (and history if one likes) closes a circle when ecology is picked up as a major theme; some of the most important early studies on the Mekong Delta were, as Brocheux also points out, made by agronomists and geographers (e.g. Yves Henry and Pierre Gourou). Closing one circle, it highlights the opening of another. Brocheux's work is a mere start of more work to be done on the relationship of environmental scarcities and social interaction and, I fear, large-scale conflicts. Given the large discrepancies between the projected economic development of the Delta and its vulnerable position, ecological considerations are bound to be extraordinarily important for the well-being of the Mekong Delta and its people in the future.

\section{Reference Cited:}

Anderson, Benedict R.O.

1983. Imagined Communities: Reflections on the Origin and Spread of Nationalism. London: Verso Editions. 